\title{
The Production of Whiteness: Revisiting Roberta Sykes's Snake Dreaming
}

\section{Alison Ravenscroft}

Those troubled terms - 'black', 'white', indeed 'race' itself-have been newly contested in recent critical theory as historicists and poststructuralists in particular have made moves to re-emphasise the historical contingency of racialised identities in the face of new efforts to reclaim 'race' for biology and genetics. ${ }^{1}$ These critical theorists vary in the ways and the extent to which they see racial differences as culturally formed but they share concerns with questions of the kind: how do specific differences come to be markers of 'race', and how do they come to signify in the ways they do? What desires and investments structure a subject's way of seeing these racialised differences? While this body of critical theory has arisen notably in the context of the United States, its terms of reference and the questions it raises are of increasing interest among Australian race critics. Here, I take up some of these terms and questions in relation to a particular cultural moment in Australia: the publication of Roberta Sykes's autobiography, Snake Dreaming, and its reception by a non-Indigenous readership. I consider the ways in which white readers have produced racialised meanings from the text; in particular, how whiteness, blackness and Aboriginality have been read, and by what signifiers. Moreover, I will be suggesting that in order to produce the meanings of whiteness, blackness and Aboriginality that are proposed in the prevailing readings of Snake Dreaming, another set of meanings has had to be erased. Against the dominant readings of the autobiography, I ask whether there isn't another story, right there on the 
surface of the page, which white readers, including myself, have had trouble recognising, and, if this is so, what processes, and what resistances, were in operation to produce that blindness. For this is a text which can be read as destabilising the definitions of whiteness and blackness which have been mobilised by Sykes's white critics; it is a text which offers a critique of the very discourses which these reading practices have reinscribed.

\section{A 'white' mother's secret}

Snake Dreaming: Autobiography of a Black Woman is, by its generic placement, susceptible to certain reading conventions and expectations. Conventionally, autobiography is read with the expectation that it will disclose stories, even secrets, which have otherwise escaped the public record. While there are other approaches to reading autobiography, especially that produced in colonial and postcolonial contexts, a reading strategy still largely prevails whereby autobiography is expected to carry the full personal story. ${ }^{2}$ In the case of Snake Dreaming it is the story of Roberta Sykes, prominent Aboriginal rights activist, that many readers have expected will be revealed, and, in a text which announces itself as the autobiography of a Black woman, these readers have expected to discover the answer to a particular enigma: is Sykes Aboriginal, or is she instead, as some have claimed, the daughter of a white woman and a black US serviceman? This then is a text which many readers have taken as promising full and certain knowledge, at last, of Sykes's racial origins.

These are hopes which the text does not fulfil. Instead, in Snake Dreaming Roberta Sykes can be said to make another move altogether, and that is to show the uncertainty and the contingency of racial identities: not only of her own, but of her white mother's and, by extension, racial identity more generally. Any hope a reader might have held for certainty of Sykes's racial identity is foreclosed. There are many ways in which Snake Dreaming can be said to do this, but one of the most significant ways is via Roberta Sykes's mother and her whiteness, a whiteness which Snake Dreaming figures as provisional. For Sykes's mother, Rae Patterson, is not given as an unambiguously white woman in Snake Dreaming, 
although this is what most published readings have made of her. While Snake Dreaming has been represented in published reviews almost exclusively as being concerned with Sykes's search for her 'black' father and his racial origins - I will turn to examples of these representations a little further on-Snake Dreaming might be more productively read as a text profoundly structured around Sykes's search for her racial identity through her mother. It is in relation to Roberta Sykes's mother that Aboriginality is chiefly associated in each of the three volumes of Snake Dreaming. A reading practice which produces the mother as unambiguously white, and which only looks to the father for the grounding of a 'black' identity, can be seen as reproducing the race relations which this text describes and resists. It is a reading practice which reproduces 'race' as lying in the colour of the skin, and 'black' and 'white' as fixed and mutually exclusive terms.

There can be no doubt as to the significance of the mother in Snake Dreaming. She is as much Snake Dreaming's subject as is her daughter, who cannot be known without her. A question mark is raised over the mother's racial background in the opening pages and remains to the very close. At the very outset of the autobiography Sykes speaks of the importance of her search for her mother. ${ }^{3}$ Snake Cradle, the first volume in the three-volume autobiography, opens with Sykes wondering of her mother: 'how much of herself did she reveal? Why did she not want to be found?' (6) To read this only, or even primarily, about the mother's secrecy over the identity of Sykes's father is to erase another meaning, for at this moment the text is referring to the mother's secrecy over her own racial identity. This, as much as the identity of her father, is what Sykes comes to suspect has been hidden from her.

In the first few pages of Snake Cradle, the mother's associations with Aboriginality are subtle; they are ones of genre. Snake Cradle opens with the story of a visitation, Sykes's mother's premonition of a death. Roberta as a small child is awakened one night by her mother's very great distress and fear: there is a presence in her mother's room, a male presence, terrifying and foreboding. The room is searched, as it will be again repeatedly during this long night while the mother is wracked by the nightmarish visits. In the relative quiet of 
the morning, a telegram arrives announcing the death of Rae Patterson's mother. The night visitor was Old Nick, death himself. This story about the mother recalls Aboriginal lifestory where such premonition of death often figures: the mother's story is given as if it, too, might belong in that lineage. ${ }^{4}$

The story that immediately follows associates Rae Patterson with Aboriginality explicitly. Sykes recalls her early memories of her mother's Aboriginal relatives:

George was a very black man with loose but kindly features and, beside him, Maggie was pale, probably a white woman, with limp brown hair.

Years later, Mum evaded my questions about Uncle George and Aunty Maggie. It was her way to become angry when pursued on subjects she didn't want to answer. I gathered she was related to George in some way, and that they were the parents of a young girl roughly the same age as me, my cousin Betty. (11-12)

The trajectory of the text that follows is that of the young Roberta's quest for knowledge of her mother's racial identity, and hence her own. It is, however, a quest which will never find its end because of her mother's evasions. For Rae Patterson, the suggestion of coming from an Aboriginal family is dangerous, for both herself and her daughters:

'Is there any Aboriginal blood in our family?' I asked ...

'Every family that's been up here for more than two generations has got a touch of the tar,' she responded ... 'Almost every family,' she corrected herself.

'Well, why don't we ever say we're Aboriginal?'

'Because we're not! ... A touch of the tar doesn't make a person an Aborigine. Nobody in their right mind would want to be an Aborigine.' (173)

She reluctantly admits that the family might have a 'touch of the tar' but refuses any inference that this makes the family Aboriginal. She nevertheless at times introduces Aboriginal people to her daughters as family. There is Roberta's cousin Hiram whose father was Jackie Ryan, champion Aboriginal 
boxer (74). When Roberta and her sister are sent to an orphanage at a time when their mother is too ill to take care of them, Rae Patterson tells them to look out for their cousin Valda, who turns out to be a young Aboriginal girl. And, of course, there is cousin Betty, whose father seems to be a relative of Roberta's mother. Snake Dreaming is shot through with such stories, where it is through the white mother that the associations with Aboriginality are being made.

It is quite possible that these Aboriginal people are family to Rae Patterson through her relationship with Sykes's father; that Sykes's father is Aboriginal. The argument I am making here does not exclude that possibility. Rather, my interest is in the fact that most readings of the autobiography exclude the figure of the mother as one through whom the association with Aboriginality may also be made. The mother is taken to be only white. Her unambiguous whiteness is taken as a given in almost all published readings of the text. This making the mother white is significant for what it must overlook in the text. It must overlook, for instance, the fact that the mother's whiteness is placed, quite literally, in inverted commas in certain places in the text; 5 it is never taken as a given in the text itself. Rae Patterson is at times represented as white and at others not white; her whiteness is not fixed or certain. I suggest that Sykes refuses to name her mother simply as white because of the ways that Rae Patterson exceeds that term and its connotations of an exclusive identity: white, and white only.

\section{Passing as white}

While Snake Dreaming carefully marks the racial identities of those who people its pages, the racial identity of the mother is oddly exempt from this. Rae Patterson's is not named as white at all until well into the first volume (95). There are markers of Rae Patterson's whiteness before this. For instance, Rae Patterson securing a bank loan to purchase a house in the context of 1940 Q Queensland would seem to position her as white, but there are always hints of another story. In order to repay that bank loan, Rae Patterson cleans houses and does laundry for local people, compelling the young Roberta to help. Sykes writes: 'it seemed somehow to fit in with what I was learning at that time - that Mum and I were expected to do a lot of work 
for white people generally' (69). Here, Rae Patterson is racially associated with her daughter, as against the 'white people' for whom she and her daughter must work.

In Snake Circle, the third volume of the autobiography, Sykes explicitly raises the possibility that her mother has been 'passing as white'. Here, Sykes speaks of her theory, 'put together from the tiny clues that had littered [her mother's] life ... that her family had been passing as white' (61). These 'tiny clues' are present in the stories Sykes recounts about her mother's life throughout the autobiography.

The practice of 'passing' is a paradigmatic case for critical race theory. In the work of Judith Butler, for example, passing as white is not understood within the paradigm of Truth: it is not taken to be a lie, or a deceit, but as a set of practices through which a subject is inserted into those social relations and their associated privileges which are read as belonging to whites. ${ }^{6}$ For Butler, being white is always a kind of passing. Whiteness is not a 'thing' but an ideal. The white subject is white to the extent that its practices approximate the ideals of whiteness: 'whiteness' then is something all whites approach but, as with all idealised self-images, can never reach. The practice of passing therefore can be seen as showing something of the constitution of race more generally and the contingency of all racialised identities. The white subject is not 'white' because of an essential quality held in the body, or on the skin, but by the position it occupies in a set of social relations, a position which successfully approximates the ideal white and which is associated with privilege. The white subject is the subject that can take up the position of white privilege.

These positions are historically mobile, with subjects read as black in one set of social relations and white in another. Noel Ignatiev in his How the Irish Became White recounts the making-white of the Irish in the United States in the course of the nineteenth century, a case sharing some features with the Australian one.7 As the 'Black Irish' succeeded in repositioning themselves within the dominant class relations, moving out of menial and transient work and into positions of greater privilege, they took up positions of whiteness. These positions are always highly contested. Irish migrants in the United 
States were prominent in struggles against the emancipation of slaves, and fought against freed blacks for paid work in the newly emerging labour relations of post-slavery capital: through successfully negotiating a coveted position for themselves in these relations of capital, and by excluding their competitors, they gained their entry into the "white race'. ${ }^{8}$ Further, race positionality moves synchronically as well as diachronically. In the Australian context, while the Irish are now white in dominant discourses of race, they occupy a more complex position within some Australian Indigenous accounts. For the Indigenous writer and critic Alexis Wright, for instance, the Irish are Indigenous because of their relation to the land in Ireland and their struggles over that land against British colonial interests. ${ }^{9}$ These examples suggest that race is produced relationally; moreover, it is neither fixed nor singular.

To take another example, Greek migrants in post-war Australia can be seen to have been positioned as black, at least until the 1970 if not still in some contexts. The derogatory term 'wog', with its association with the danger of infection, suggests that the Greek migrant was positioned as a carrier of illness into white Australia. That illness was the illness of the other, in this case of non-whiteness. (In the US context, the term 'wog' has been used derogatively to denote blackness. $)^{10}$ As Greek migrants, like their Irish counterparts, have moved out of seasonal work and off assembly lines into positions of greater socioeconomic privilege, as they have moved into more secure positions within dominant class relations, they too have been whitened within Australian race discourses.

Passing as white therefore is not to pass from a 'true' race identity to an 'inauthentic' one; it is to move between two positions, one designated as black, or, more precisely, not-white, the other designated as white. This is why passing can be seen to produce anxieties, both for the subject who is said to 'pass' as white, and for the subject who is said to 'be' white. For the subject who passes, will they be white enough? For those who successfully occupy the position of white, will they be able to secure it, hold it? Is whiteness and the privileges accorded it at risk if permeated by the racialised other? 
This is not to say that there are not profoundly held attachments to racial identities, or that racial identities are not deeply significant. It is rather to say that those identities are formed in the context of racialised social relations, and that the subject is produced as white or black according to historically shifting signifiers.

And, indeed, throughout Snake Dreaming, Rae Patterson is 'white' at those times when she succeeds in locating herself in a set of relations and practices in which she will be seen to be white, that is with those privileges denoting whiteness, and she is 'less white' when she cannot insert herself into these relations. So, to return to the example of Sykes's account of her mother's domestic work for whites. Here, Patterson's whiteness appears to be compromised, and while the reason isn't made explicit, if we take the suggestion that whiteness is about positionality and a concomitant set of practices, then it might be said that in domestic work Patterson was not comfortably positioned within these set of relations and practices. The work is done generally by poor and disenfranchised women, and in the context of north Queensland in the 1940s and 1950s, this is racialised: this is the kind of work done by Aboriginal domestic servants. This structural proximity to Aboriginal women's labour compromises Rae Patterson's fragile hold on her own whiteness.

Paradoxically, Rae Patterson puts herself in the position of a domestic servant, with its proximity to Aboriginal women's labour, in order to secure for herself and her daughters some financial security which will in turn offer some of the privileges of whiteness: through her work she hopes to gain some degree of financial security, some independence from the prying eyes of welfare, some justice. However, these privileges of whiteness turn out to be not only privileges but the very signifiers of whiteness. When Rae Patterson secures the privileges of whiteness, when she possesses the accoutrements of middle-class respectability, she will be read as white.

Rae Patterson desires to position her daughters as white through privilege. She sought the privileges of whiteness for her daughters in order that they would be seen as white. There were piano lessons and dance lessons, there were pretty lace dresses and patent leather shoes. To Sykes it seems that there 
were times when her mother believed she had accomplished this making-white of her daughters, such that she 'saw' her daughters as if they carried the signifiers of whiteness on their bodies: 'I began to realise that when Mum looked at us she didn't see us. She patted our long golden locks, stared into our deep blue eyes, and fixed us up in dresses and hair ribbons to match the peaches and cream complexions she saw on us.' (Snake Cradle, 173)

But, if Rae Patterson believes at times that she has succeeded in making her girls white through privilege, she knows that it is always provisional, contingent on the context she can produce for them. Thus, in the event of the rape of the young Roberta it is perfectly clear to Rae Patterson that Roberta is now not-white: that she is being positioned as a black girl, indeed as an 'Abo'. This is why she was raped and why she would have been treated as if abject had she taken the case to the police. Rae Patterson must make her daughter white if she is to have the police take her case and their inquiries seriously, if she is to have any justice at all. Rae Patterson endeavoured to make her daughter white and this making white depended on whether she could mobilise her own whiteness as a context in which her daughter could, in her turn, be read as white. As Sykes says:

My mother's valiant desire to be a white woman in a world she recognised as intrinsically racist, had, in the end, been a godsend for me ... I felt sure that, initially, only my mother's 'whiteness' had prompted the police to begin their inquiries. (326)

Here Rae Patterson's whiteness appears in inverted commas to denote its uncertainty. The text binds Rae Patterson's whiteness inextricably with her desire for and practice of whiteness. Rae Patterson is white to the extent that she can successfully practise whiteness. Hers is a 'valiant desire', with all the bravery that those words connote. This is a story of race as struggle, violence and negotiation, rather than the colour of one's skin. 


\section{'White' readers}

The conventional expectations of the autobiographical genre have not been fulfilled by Snake Dreaming. Where a reader may have hoped to find certainty - in this case, certainty concerning Sykes's origins - there is only uncertainty. The text shows the groundings of this uncertainty: it shows why the quest for certainty of racial origins cannot be satisfied. Yet for some readers of the autobiography, Snake Dreaming remains at best an unfinished account of racial identity and origins, and, at worst, one that is untruthful. Snake Dreaming has been read as a text which withholds from or even lies to its readers.

The appearance of the second volume of Sykes's autobiography in late 1998 attracted a flurry of media attention which focused precisely on the question of the truthfulness of Sykes's alleged claim to Aboriginality. This is not a claim Sykes makes for herself anywhere in the autobiography, preoccupied as that text is with the uncertainty of origins. Nevertheless, Luke Slattery in The Weekend Australian, for instance, charged her with claiming an Aboriginal identity, and then set about proving it to be false. Under the heading, 'Sykes is not Aboriginal, says the one who knows best ... her mum', Slattery maintained that Sykes does not have 'a drop of Aboriginal blood'. ${ }^{11} \mathrm{His}$ claims were based on a report in the Brisbane Sunday Sun twenty-five years previously where Rae Patterson is quoted as saying of her daughter: 'Her father was a negro [sic] soldier ... I am Roberta's mother and I am white.' For Slattery, this 'telling testimony' from her mother undermines the credibility of any claims Sykes might make to Aboriginality. At the same time, Slattery also recalled how very unreliable Rae Patterson has been on the question of Sykes's paternity in the past. Sykes's father, Slattery wrote, 'was variously described to her by her mother as Fijian, New Guinean, or part-Negro and partCherokee Indian'. Slattery's account slides over the implications of this, and Rae Patterson's words are made to take on the weightiness of truth: her words now can fix the question of origins once and for all. ${ }^{12}$ Slattery has here 'improved' upon Sykes's own efforts: he has done what Sykes was unable to do, and that is made the father's racial origins certain. Moreover, Slattery elides the other constitutive uncertainty of Sykes's narrative and that is the uncertainty of the mother's racialised 
identity. The mother says she is white, Slattery reports, therefore she is white, and only white. Slattery now can make a set of clear and certain claims: the father is not Aboriginal, the mother is white, and therefore their daughter cannot have 'a drop of Aboriginal blood'. ${ }^{13}$

The kind of reading practice which propels commentary of this kind takes Sykes to be the sole producer of textual meanings. It is Sykes who makes herself Aboriginal in her text, it is Sykes who claims this alleged heritage through her father (only), it is Sykes who makes her mother white (only). But, given the evidence from the text, we might need to ask: what of the reader's part in the production of these meanings? What discourses about race prevail such that these meanings are available, while others are less so? What suggests the kind of reading that Slattery, like many others, has performed?

Most published commentaries read Snake Dreaming within discourses which have white and black (including Aboriginal) racial identities as dichotomous and mutually exclusive. Like all dualisms, this one produces the 'inferior' term as the dependent one. Therefore 'blackness' is intelligible only in terms of whiteness: in other words, 'black' stands in for 'not white'. The subject who exceeds or destabilises this dichotomy is not taken to be both black and white. This possibility is excluded by the logic of the dualism where black is really 'not white': one cannot be white and not white. This logic produces those practices of racialisation whereby the subject is either resolved into a single identity - white or black-or sentenced to an 'in between', neither white nor black. This refusal to allow doubleness or ambiguity is raised by Sykes in the prologue to the final volume of her autobiography:

'I wish you wouldn't keep calling yourself BLACK. You're not BLACK.'

I'm surprised that this white woman would think I should take her wish-list on board, as if I have no wishes of my own.

'So - am I white?' My question is rhetorical, my dark skin and hair a brazen confrontation.

'Well, no. You're not black and you're not white. You're perhaps sort of somewhere in between.' (v) 
Given the logic of the dualism where 'black' stands in for 'not white', the 'in between' is not a third position at all. It is another 'black'. It is the position the subject falls into when the requirements of whiteness have not been met.

If Sykes is read as black, or, as her interlocutor puts it, 'somewhere in between', her mother is resolved into a singular whiteness in most commentaries. ${ }^{14}$ Even among those reviewers who offer more sympathetic readings of the autobiography than those which appeared in the daily press, and who are sensitive to the story of racial tensions the autobiography describes, the mother's whiteness remains a clear and certain thing. Cassandra Pybus, reviewing the final volume, Snake Circle, for Australian Book Review, reasserts the father's importance in the mystery of Sykes's racial identity and reasserts, too, the certainty of the mother's racial identity: 'The problem for Sykes is that she does not know her country or her people; she cannot say who her father was. Her white mother will not tell her.' ${ }^{15}$ Dianne Dempsey, reviewing Snake Circle for the Age, similarly writes: 'Sykes has always maintained that her white mother refused to divulge her father's race. ${ }^{96}$ Anne Summers published a sympathetic reading of the second volume, Snake Dancing, in the Age, placing the text in a wider historical context and so broadening the terms of the debate. Her essay begins by quoting from an important passage in the volume, where MumShirl, Aboriginal community and cultural worker, is shown challenging Roberta - not for her claims to Aboriginality but for her seeming refusal to stand by that identity:

She said she had heard that I was telling people I wasn't Aboriginal, and asked if I knew how much this insulted Aboriginal people?

'Well', I replied, 'I can't prove that I am. I have reason to think I am, but I can't prove it.'

'But,' said MumShirl, 'can you prove that you're not?'17

Summers, however, pulls short of showing the fuller meanings of this passage. The extract leaves undisturbed the prevailing assumptions that it is Sykes's father whom Sykes believes may have been Aboriginal. There is nothing in Summer's extract 
to suggest that it is Sykes's mother's background which Sykes has reason to believe is Aboriginal. Yet the next sentence in the same passage draws a very different picture: 'my mother', Sykes says, 'was secretive about her own ancestry' (153).

There have been some important exceptions to this reading practice. ${ }^{18}$ One of these is by Aboriginal novelist and critic Alexis Wright, who, reviewing the first volume of the autobiography for Australian Book Review, put her finger on the complexity of race relations which Sykes's autobiography describes when she observed how:

Sykes explores the depth of the personal veneer surrounding every Australian who is, like it or not, part of the hidden history of black and white contact in this country. Secrets taken to the grave choke every cemetery in Australia. ${ }^{19}$

This 'hidden history of black and white contact' lies at the heart of Sykes's autobiography, carried in particular by its story of the white mother who might be the carrier of an Aboriginal heritage for her daughter. In reading practices which produce the mother as only white, the history of black and white contact is once more hidden. This is not to suggest a conscious choice to hide or deny that history. It is instead to suggest that the history of black and white contact of which Alexis Wright speaks is hidden because of a disavowal, ${ }^{20} \mathrm{a}$ disavowal of the kind: 'I know that contact between black and white has occurred in this country but, still, I believe that it has not.' That is, a repression of the knowledge of black and white contact and the effects this may have had, including on whiteness. Contact with Aboriginality must transform whiteness or, in the terms of racist discourses, 'pollute' it. This is the 'brush with tar'. The desire to hold on to the belief that there has been no contact between whites and blacks, 'not in our family', is very strong and is represented powerfully by Sykes in her portrayal of her mother. The kind of disavowal which Sykes describes in her text, and which is evident in the reading practices of some of her critics, has powerful effects, ones which cannot be underestimated in Australia at this historical juncture. 
This opens up questions concerning the investments readers might have in the maintenance of the white/black dualism. If Snake Dreaming is read as problematising prevailing notions of whiteness, showing that it is never the pure thing that White Australia wishes it to be, and that it is not fixed and certain, but unstable, not natural but contingent, then there is the troubling question: what certainty of racial identity exists for the 'white' reader? Sykes's text implies that white readers cannot take for granted the stability of our own whiteness, and suggests the disavowed proximity of Aboriginality in White Australia's history.

\section{Reflection}

Although this essay on the reception of Roberta Sykes's autobiography Snake Dreaming was written in the context of whiteness studies - which was just then emerging as an academic discipline in Australia-it is as much indebted to another moment, thirty years ago now, when at the 1984 Women and Labour Conference in Brisbane I first encountered the powerful challenges to white feminism made by a number of Aboriginal women, Jackie Huggins, Lilla Watson and Jo Wilmot among them. These women resisted feminisms that sought, however unwittingly, to colonise Aboriginal women by re-centring white women as the speaking subjects who could speak for and about Aboriginal women and Aboriginal cultures. Huggins, Watson and Wilmot were arguing against white feminists' claims to know, and to speak for, Aboriginal women, arguing that white women saw gender relations in Aboriginal cultures through white feminist interpretative frames that distorted Aboriginal cultures, making them appear as versions of western cultures. More than this, they argued that white women's knowledge of themselves and their own culture was itself limited. White women, they argued, were blind to their own colonising impulses, historically and into the present.

This moment held formative possibilities for the many young feminists in the University of Queensland auditorium that day who, like myself, found themselves in the deeply uncomfortable position of being the far-from-ideal objects of Aboriginal women's gaze. The effect was surely redoubled by the fact that the women were insisting on our blindness.

Since then, questions of the visual field of race and how vision 
is shaped by our desires to see-and not to see-have increasingly entered into critical race studies. In this essay, the emphasis is on the many non-Indigenous readers of Sykes's trilogy who were unable to see that Roberta's association with Aboriginality came through her 'white' mother and not her 'black' father. Here, by 'white' and 'black' I mean those highly provisional and movable positions that are written by and read within racist regimes as fixed and naturally formed categories based in skin colour. The paradox for Sykes was that her text critiqued the very discourses of 'black' and 'white' that her non-Indigenous critics mobilised against her. What desires shaped these critics' vision?

How to read 'black' and 'white' in Australian literary and autobiographical texts remains highly contested, as it must. The question of how to deconstruct this troubling and violent pairing, how to speak about its continuing effects without giving it new life, is as urgent now as it ever was. At the time of Snake Dreaming's publication, Alexis Wright said: 'Sykes explores the depth of the personal veneer surrounding every Australian who is, like it or not, part of the hidden history of black and white contact in this country. Secrets taken to the grave choke every cemetery in Australia.' Those histories of contact remain secret so that the fantasy of whiteness can be sustained. Recent fiction, including by Wright among others, pushes the fantasies of a knowing white subject to its limit; indeed, to breaking point. These are new moments in the long history of Aboriginal women and men 'talkin' up. ${ }^{21}$

\section{Notes}

For an account of recent arguments of natural scientists on the genetic constitution of 'race', see Charles Shepherdson, 'Human Diversity and the Sexual Relation', in Christopher Lane (ed.), The Psychoanalysis of Race, Columbia University Press, New York, 1998. In critiquing some discourses of race-specifically those concerned with whiteness and blackness - I use the same vocabulary which I am critiquing: 'black', 'white', the word 'race' itself with its connotations of an essential meaning carried on and in the body. One of the paradoxes and limitations of critique is that it reproduces the very terms it seeks to undo. The limits of autobiography as a genre and of the reading practices conventionally associated with it have been critiqued in the context of colonial (textual) relations where Indigenous lifestory are understood to exceed the generic expectations. For a discussion which resituates Aboriginal 'autobiography' as testimony, for instance, see Rosanne Kennedy, 'The Narrator as Witness: Testimony, Trauma and Narrative Form in My Place', Meridian, vol. 16, no. 2, October 1997, pp. 235-6o. 
a Black Woman, Allen \& Unwin, Sydney, 1997, p. 8. All subsequent references to this work appear in parentheses in the text.

See Aileen Moreton-Robinson, 'Tellin' it Straight: Self-representation within Indigenous Women's Life Writings' in Moreton-Robinson, Talkin' up to the White Woman: Indigenous Women and Feminism, University of Queensland Press, Brisbane, 2000.

See Snake Cradle, p. 365; and in the third volume of the autobiography, Snake Circle, Allen \& Unwin, Sydney, 200o, p. 242. Subsequent references to this work appear in parentheses in the text.

6 Judith Butler, 'Passing, Queering: Nella Larsen's Psychoanalytic Challenge', in Butler, Bodies that Matter: On the Discursive Limits of 'Sex', Routledge, New York, 1993, pp. 122-38.

$7 \quad$ Noel Ignatiev, How the Irish Became White, Routledge, New York, 1995.

8 On the questions of the Irish immigrants and the anti-slavery movement, see William Freehling, 'The Divided South, Democracy's Limitations, and the Causes of the Peculiarly North American Civil War', in Gabor S. Boritt (ed.), Why the Civil War Came, Oxford University Press, New York, 1996. Also, see David Roedigger, The Wages of Whiteness: Race and the Making of the American Working Class, Verso, New York, 1991.

9 See my interview with Alexis Wright in 'Politics of Exposure: An Interview with Alexis Wright', Meridian, vol. 17, no. 1, May 1998, pp. 75-8o.

10 For a discussion of the foreigner as black in twentieth-century literary discourses in the United States, see Walter Benn Michaels, Our America: Nativism, Modernism, and Pluralism, Duke University Press, Durham, 1995.

11 Luke Slattery, 'Sykes is not Aboriginal says the One Who Knows Best ... Her Mum', Weekend Australian, 24-25 October 1998, p. 11.

12 In Snake Circle, Sykes herself comments on the Sunday Sun's report of 1973, noting: 'Mum's own racial background had not been questioned. As long as the papers described her as "white", she wasn't obliged to clarify and neither did she object', p. 242.

13 By way of a reply to her readers, Roberta Sykes published an essay in the Australian in which she spoke of her incomplete knowledge not only of her paternity but of her parentage, and she referred to both her mother and father when speaking of her wish to be known for who she is, not who her parents might have been: 'I hoped my book made clear the fact that knowing so little about my parentage has been of tremendous disadvantage in that I do not have the luxury of being able to make any claim at all in terms of clan or extra-familial relationships, but rather I have always hoped to be judged on the basis of what it is that I have done and do, rather than what my mother or father may have done or who they might have been.' The implications of this went unnoticed in the press, where Sykes continues to be represented as the daughter of a Black American serviceman and a white woman. Roberta Sykes, 'In the Public Interest?', Age, 24-25 October 1998, p. 27.

14 Jon Marsh wrote in the Age, under the heading 'Aboriginal voices turn on one of their own', claimed: 'Dr Sykes, in her autobiography Snake Cradle, says she was raised by a poor, white, single mother who told her various stories, the most consistent being that her father was a black US serviceman'. Jon Marsh, 'Aboriginal Voices Turn on One of Their Own', Age, 17 October 1998, p. 3. Kevin Meade, writing for the Weekend Australian, argued that: 'Dr Sykes says in Snake Cradle that her mother was white and her father, whom she never met, may have been a black US serviceman', a claim he was to repeat a few days later. Kevin Meade, 'Activist had black view of racist world', Weekend Australian, 24-5 October 1998, p. 11, and Meade, 'Writer's Snake Claim Speared', Australian, 21 
October 1998, p. 5 .

15 Cassandra Pybus, 'To Harvard and Beyond', Australian Book Review, July 20oo, p. 6.

16 Dianne Dempsey, 'Political, Personal, Powerful', Age, Saturday Extra, 8 July 20oo, p. 7 .

17 Anne Summers, 'Under the Skin', Age, 10 October 1998.

18 See Anne Waldon Neumann's reading of Snake Cradle in Meanjin in which she speculates on Rae Patterson's 'mixed descent', Anne Waldon Neumann, 'Pity, Terror and Admiration', Meanjin, vol. 57, no. 2, 1998, p. 374. Also see the Indigenous writer Sonja Kurtszer's essay in Australian Feminist Studies, vol. 16, no. 34, 2001, pp. 101-11.

19 Alexis Wright, 'Secrets and Shame', Australian Book Review, November 1997, p. 33 .

20 In psychoanalytic theory, the formula for disavowal is given as: 'I know very well, but still .... For a concise description of this, see Slavoj Zizek, 'How did Marx Invent the Symptom?', in Zizek, The Sublime Object of Ideology, Verso, London, 1989 , p.18.

21 Moreton-Robinson, Talkin' up to the White Woman. 